\title{
Consolidating the Gains and Reshaping the Future of Democracy in Nigeria
}

\author{
Peter B. Bisong ${ }^{1}$, Asira E. Asira ${ }^{2}$ \\ ${ }^{1,2}$ Department of Philosophy University of Calabar, Nigeria \\ E-mail: pbbisong@yahoo.com ${ }^{1}$
}

(Received: May-2020; Reviewed: July-2020; Accepted: July-2020;

Avalaible Online: July-2020; Published: July-2020)

This is an open access article distributed under the Creative Commons Attribution License CC-BY-NC-4.0 @2020 by author (https://creativecommons.org/licenses/by-nc/4.0/)

\begin{abstract}
Nigeria has practiced uninterrupted democracy from 1999 to date. She has however, little to show for this long practice of what was hitherto perceived as the harbinger of good things. This paper argues that the slow growth of democracy in Nigeria, has nothing to do with a defect in democracy itself, but with the nature of Nigerians. Democracy viewed on its own is good, but the way it is practiced in Nigeria has made it not to flourish. The paper recommends steps to be taken by all Nigerians, in order to consolidate democracy and to reposition it for future dividend delivery.
\end{abstract}

Keywords: Democracy; dividends delivery; corruption; consolidation

\section{INTRODUCTION}

Consolidation carries with it ideas of achieving part or full of what one sets out to do thereby thinking ahead into the future how to maintain, sustain and retain the gains so far attained or obtained. Considering the above, many questions will crop up in any rational mind: what did Nigeria set out to achieve through democracy? Has it been partly or fully attained? How is it to be sustained? This and the like questions may be attended to sometime somewhere. However, if Nigeria has or not set out to achieve anything, and has or not achieved anything, it calls for sober reflection. Thus, this will not be the main focus of our paper. We will concern ourselves more seriously with the last question - how democratic gains can be sustained or consolidated.

The paper is divided into three main parts. The first part will attempt to show the perceived gains of democracy in Nigeria. The second part will delve into the crux of the work: how the gains of democracy can be sustained. This section will lay out the various factors necessary for the gains of democracy to be sustained or consolidated. The third part will spell out the practical steps to be taken to bring about a consolidated democracy in Nigeria. 


\section{The Gains of Democracy in Nigeria}

Abraham Lincoln in 1863, defined what is now considered the ideal definition of democracy, as "government of the people, by the people for the people."This means that, democracy is a kind of government whereby the people control their activities and lives, by partaking in decisions about how they are governed. They are different forms of democracy which are broadly categorized into "direct" and "representative". Representative democracy is a form of government where the people participate in their government indirectly by electing people to represent them - this is a form that Nigeria practices (Irek 2016).

Nigeria has practiced representative democracy since 1999 when the military handed over the reins of power to a civilian ruler (Anweting \& Ogar 2018). Though, many people believe that democracy has not fared well in Nigeria and thus has failed to yield the expected dividends, many others believe that democracy has yielded some dividends in the country. A spokesman for Save Nigeria Group, Abiodun Sowumi is one of those who believe that democracy has yielded much in Nigeria. He argued that democracy had engendered freedom of choice of political leaders, made possible better system of accountability, improved freedom of expression and enhanced greater respect for human rights as well as economic progress among other gains. He asserts "even without the rebasing of the economy that now makes it the largest in Africa, we've seen the economy expands. There is a huge economic activities going on in terms of development of infrastructure either by the state or the federal government." (Ogunbumi, 2015). Senator Victor Ndoma-Egba, also believes that all is not bad about Nigeria's democratic practice. He commented on this thus:

When we are doing an assessment of how the country has fared since 1999, I will like to categorize the assessment into tangibles and intangibles ...The tangibles are those aspects people can construct with their senses, either with the sense of vision or the sense of touch. Then the intangibles of course are those imperceptible things you cannot see or touch... Now for the intangibles, I think the most remarkable is that this is the longest episode of our democracy in our post-independence history. We have had a number of episodes of democracy in our long years of military rule. 16 years unbroken is the longest that we have experienced and for me it is a major achievement and that we have achieved this long of episode without compromising any of the freedoms guaranteed in the constitution is again a major achievement (Ogunbumi, 2015).

On his part Clifford Ndujihe asserts that:

There are certain gains that democratic rule in Nigeria has afforded us and they must be acknowledged despite all the shortcomings of Nigeria's version. For example, we have freedom of speech far better than we did in the past. There is also a much freer press than we had in the past. The recent case of Leadership Newspapers vs. Federal Government shows us how far we have come. Some 20 years ago, that would have been a totally different story and a totally different outcome from what we have now... To an extent, too, there is a judiciary that still manages to serve as the last hope of the common man. Once in a while, a public official even manages to get sent to jail for economic crimes. These are the gains of democracy in Nigeria and though they might appear insignificant or inadequate, they still constitute a step forward compared to where Nigeria traveled from to arrive here. We have even progressed enough to have the Freedom of Information Bill signed into law (ThankGod 2018).

Many people do not share in these sentiments of those who believe democracy has yielded results. They believe that the results are too minimal to be counted as such. As captured by the Tide Newspaper, they argue that 
The country remains impoverished by many indications...In the 20 years between June 12, 1993 election and today, Nigeria has earned enough money to create a Dubai in each of the six geo-political zones and make our citizens some of the most prosperous people on earth, but what we have instead is collapse of infrastructure, deepening poverty (70\% rate from $45 \%$ in 1999), social dislocations, high unemployment rate and violent crimes (ThankGod 2018).

It is true that democracy in Nigeria has not achieved much but this does not mean that it has not achieved anything. It is our belief that with time, much more will be reaped from this democracy because it is still maturing. No democracies in the world just got it right at once, it followed a process of maturity. Nigeria will get to that point where the democratic dividends will be very evident, if it is able to consolidate on the gains already made.

\section{Factors Necessary for Consolidation}

An individual or group can consolidate gains only when there is; unity of purpose, mutual trust and respect, good political leadership and good moral relationship with one another. We will discuss these in details.

\section{Unity of Purpose}

A society that is bereft of common interest would not achieve meaningful progress in all strata of its life. It is true that each individual along as he/she is human is unique and therefore has personal goals, aspirations and interests (Edet 2017). However, a society man is rationally expected to be able to manage these goals and interests so that there would not necessarily conflict with the societal goals. What are the goals of Nigeria as a nation? What interest(s) does it fight for? What future does it crave for? What in the past does it want to correct or sustain? For these and many more to be attained, the citizens of Nigeria need to be united in their visions and purposes. They need to drop their personal interests especially those that conflict with the collective interest to pitch tents with the common good.

The Bible clearly states that two cannot walk together, if they do not agree. Nigeria cannot walk together to the future they crave for if they do not agree. Diverse interests must therefore be converted to a collective interest. It is in working in unison that mighty tasks could be accomplished. Innocent Asouzu captures this in his well celebrated concept 'Ibuanyidanda' which means, "no load is insurmountable for danda the ant" (Asouzu 2017a, 11-12). The ants he observes, when working in unison are capable of carrying loads that are far heavier than them. It also implies that when humans work in unison or in singleness of purpose, they can surmount otherwise insurmountable tasks. If Nigeria citizens work as one, they would surprise the world with their achievement. But they cannot work as one if there is no mutual trust and respect.

\section{Mutual trust and respect}

In the early days according to Thomas Hobbes, the life of man was brutish and short; there was mutual suspicion and thus it was a state of war against all. In this primitive state, everybody was an enemy of everybody. The formation of a social contract gave rise to modern day society, where life according to Hobbes is peaceful and enjoyable (Hobbes 1951; Egbeji 2019). It is however, unfortunate that this state of nature that Hobbes thought has been overcome by the formation of the social contract is re-emerging (Duke \& Osim 2020). In our society of today, there is this mutual distrust that is rearing its ugly head and threatening to take man back to the Hobbesian state of nature (Alumuna et al 2017). 
There cannot be meaningful progress in a state where everybody is afraid of everybody. This scenario is depicted by the reigning slogan "in politics there is no permanent enemy and no permanent friend". This means that a friend today could erratically become an enemy tomorrow. It also implies that one need to trust no one, because the one he/she trusts could betray him or her at any time without warning. With this mindset of collective distrust, nothing worthwhile could be achieved. This is one reason Nigeria is finding it hard to make progress. Ethnic groups constantly pitch themselves against themselves: A Yoruba man is not comfortable with and does not trust a Hausa man, a Hausa man sees an Igbo man as suspect. Even within the individual ethnic groups, there is infighting occasioned by distrust. The family too is not left out, brothers fight against brothers and sisters and vice versa. The Nigerian climate is therefore, that of hostility, fear and mutual distrust. Nigeria is like a magnetic object that has lost its magnetic effect due to the scattered arrangement of electrons, for electrons need to be arranged in a particular orderly format before the object could be magnetic. Nigeria is not able to work as one because there is no attracting force but rather a rebelling force that is occasioned by mistrust. I am of the belief that unless Nigerians begin to trust and respect one another, Nigeria will not move beyond this level. Unless they respect the personhood and rights of each person, looting, maiming, killings etc will not cease. When mutual trust and respect reign supreme that is the moment where all stakeholders would see other human beings as missing links of reality that deserves the best of services. Asouzu believes that all that exists serves a missing link of reality and any action that negates this receives the boomerang effect (Asouzu 2017a, 10). This means that harming the other is the same as harming the self; destroying the other tantamount to shooting oneself at the foot. To negate the other is to negate the services, that other would have rendered to the self. Every person is important and contributes to the realization of a meaningful existence of the self, though sometimes indirectly. For instance, Mr. A may help Mr. B and Mr. B extent this help to Mr. C. It will be stupid of Mr. C to assume that Mr. A is not important and thereby should be eliminated because he does not directly help him. Destroying Mr. A will tantamount to depriving Mr. B of the services rendered by Mr. A, and this will inevitably affect Mr. C who will not be able to receive the services of Mr. B who is incapacitated by the death of Mr. A. This is why, Asouzu believes that all that exist "serves a missing link of reality" (Asouzu 2017a, 10). This means that all that exist, exist in a complementary relationship with one another, such that when this complementary relationship is tempered with the effect is circulated unconsciously to all, and when this relationship is maintained and preserved, all will benefit positively.

When this mindset takes root in all people that, is the moment mutual respect will be instituted. It is also the moment that good working relationship which is essential for growth and development will ensue. Good human relationship is directly depended on the level of trust existing among the humans concerned. When people trust themselves, the relationship existing among them will be strong. According to Pat Mesiti, when signing the Declaration of Independence, Benjamin Franklin said "we must all hang together or else we shall hang separately" $(1997,20)$. However, unity only comes when there is mutual trust. Development of mutual trust is heavily depended on good leadership.

\section{Good Leadership}

Hobbes believes that the war against all and mutual distrust in the state of nature ceased when all handed over their rights to a sovereign or leviathan. The leviathan had the power to make laws and punish accordingly. Because the difference between the primitive state and the civil state was the Leviathan, it is rational to assume that if the Leviathan failed in his duty, the state of nature would emerge again. This implies that Nigeria is gradually relapsing back to the 
state of nature because of the failure of the Leviathan (leaders) to execute their function. Leaders control through laws, but when the laws fail to bite, what becomes of the society? Nigeria laws fail to bite. Consequently, no body fears the laws in Nigeria, because they all know that the law catches only those who are not able to pay. As long as one is able and willing to pay the law passes such an individual by, no matter his/her level of corruption. Nigeria is a country where justice is for the highest bidder. This is a failure of leadership. If all had the confidence in the laws of the country, then mutual trust will increase. This is because, one will be conscious of the fact that the other would not want to do wrong at least for fear of the law. But where there is no fear of the law, there is fear of the other, because what he could do become unpredictable.

If Nigeria wants to consolidate their gains for a better future, it leaders must ensure that justice is not put for sale but is made available to all and sundry. Nigerian leaders should be more concerned with making people than with making money. A call to leadership is not a call for money making; rather it is a call for service - a service that should produce more leaders than followers. It is a service that should produce more free and happy people than slaves and beggars in their own land. It is a service that should produce a self-reliant society instead of a merely dependent society which totally depends on allocation from the federal government (Irek 2018). Nigeria is blessed with fertile land, numerous human and other resources. These could be fully harnessed to elevate the country to a ladder never reached by any country, if the leaders are focused and have the people at heart.

The kinds of leaders a society has determine the progress of the society. This is the reason, Plato the ancient Greek philosopher advocates for a philosopher-king leader. For him, a leader should have the adequate skills for leadership which comes through much academic and physical training. In Nigeria anybody could just come up and wants to lead, and he is voted into office because he has money to throw around. It is high time, that the masses, especially the educated and informed youths arose to ensure that this is corrected. Leaders should be carefully and critically selected and not forced on the people. It is when Nigeria begins to get good leaders that the country will be straightened. It is when Nigeria begins to get good and responsible leaders that things will begin to go right. However, good political leaders alone cannot do it all; there must be a complementarity of efforts between the political leaders and the spiritual leaders or religious leaders. Good religious leadership imbues morality in the minds of Nigerians and thereby make them relate better with one another.

\section{Good Moral Relationship}

Religion is aimed at producing moral individuals. Morality needs to work hand in hand with laws for an effective control of human conducts (Udoudom et al 2018; Ushie 2018; Ogar et al 2018; Duke \& Okafor 2020; Yta 2020). Laws no matter how effective cannot catch all criminals due to its nature. For law to catch an offender, the offence must be observed by someone and reported. But only few offences are observed. And even these few ones that are observed, not all are reported because of the cost of getting legal sanctions on an offender. It is expensive to bring a criminal to book especially in the Nigerian context where justice goes to the highest bidder. But morality by its nature catches all offenders whether observed or not. For instance, one does not need to be observed before he feels guilt or anguish for a wrong act. Also the cost of getting moral sanctions is negligible. For instance, it cost nothing for one to feel guilt. It cost nothing for condemnation and castigation to be heaped on an offender. Thus morality by its nature penetrates into areas that law cannot. This however, does not mean that morality can do all by itself alone. There are some areas that morality cannot operate like, in human to environment relationship. Morality does not regulate the handling of the environment (Udoh 2017; Akpan \& Bassey 2020). For instance, a man could set a whole bush on fire, killing 
thousands of living things. To the society this act as long as it does not harm anybody is not immoral. Such a person could continue to walk tall in the society and is seen as moral. But to law this is wrong. This is why I believe alongside Bisong that a complementarity of the two (law and morality) is very necessary for a society to function well (Bisong et al 2014, 29-36).

It is however, unfortunate that the religious leaders on whose soldiers rest the responsibility of instilling morality on the people have turned to entertainers, telling the people what they want to hear. The churches are now filled with messages of prosperity, miracles and promises of fairer future. Messages on morality are now shifted to the back seat. The church leaders now think more of how to exploit the people than how to help them to gain salvation. The Nigerian religious leaders have failed in their task, making Nigeria to fall into moral ineptitude. This is why Nigeria for many years has been named by Transparency International among the most corrupt countries in the world.

\section{What to do to Achieve Consolidation}

For Nigeria to stand, all must do their parts. The political leaders must ensure that the laws bite and that they rule well, the religious leaders must ensure that morality is instituted in the heart of Nigerians and even the ruled must make sure they become good followers. All hands must be on deck. This is what Chris Ijiomah describes in his concept of 'harmonious monism;' he argues that there is need to submit the explanation of our realities to different logics (2014, vii). This means that, no logic is absolute. The various logics must be harnessed into a monism to achieve success. G. O. Ozumba supports this in his 'Integrative Humanism'. Ozumba believes that no knowledge is useless; all knowledge could be harnessed and integrated to yield a useful result $(2010,23)$. This means that our differences should not be a disadvantage but an advantage, for when these differences are harmonized and integrated there could form a synergy that will catapult Nigeria into unsurpassed success. There must therefore be harmony of all efforts to ensure a good and sustainable Nigeria. Other tips include:

1. Focus on opportunities rather than problems: there is a story of two young men who were sent by a company to go for a business survey of a certain community. The first man reported that there was no chance of success for the company, because nobody in the community wore shoes - no need to supply shoes to them because they will not patronize the company. The second man reported enthusiastically that there is abundance of opportunity for the company, explaining that ten thousands shoes could be sold to the dwellers of the community because none had shoes. The company took the advice of the second man and made tremendous sales. The first man saw not having shoes as a problem and the second sees this as a tremendous opportunity. This shows that life appears to us the way we look at it. The concept 'Godisnowhere' could be seen by some to read; God is nowhere and to some as, God is now here. Everyone needs to learn to look at the positive sides of everything. As long as Nigerians refrain from dwelling too much on the problem but on the opportunities to be tapped from the situation. The community will begin to make awe inspiring achievement. For it is those who see opportunities where others see failure that get to the top of their chosen endeavor. Dare to dream beyond your peers and you will lead them.

2. Choose your own direction rather than follow the band wagon: those who attempt to be like others end up living in the shadows of others. We are all unique in all ways and therefore can only live meaningful lives if we allow our uniqueness to shine forth. Nigeria has to discover what makes it unique and develop this uniqueness to perfection. Attempting to imitate what gives success to other societies will lead the country nowhere. A man succeeds better if he discovers and develops his talents. Nigeria and indeed all societies 
will succeed better, if they discover what unique gifts they have and develop them to the fullest.

3. Work against individual gratification: The instinct of self-preservation naturally leads all to seek to preserve their interests. For Asouzu this instinct is the root cause of all conflicts and ethnocentric tendencies (Asouzu 2007b, 170). It makes one to fight for his own interest even if this negates the interest of the others. Authentic living involves going against this crude instinct - the instinct that ruled primitive people. The best way to preserve the self is not to negate the interest of the other but to protect and preserve the interest of this perceived other. This is because the other is an essential part of the self. Where there is no other there is no self, for whatever exists must exist in a complementary relationship with others - no one exists in isolation. Based on this therefore, it is pertinent to work for the self through serving others; it is through serving others that the self receives the best of services. This is the reason why Jesus admonishes that whoever wants to be the greatest should serve. The greatest indeed is he who serves and preserves the interest of others as a means of preserving his own interests and goals. Those who seek to gain personal gratification in negation of that of the others indirectly works against themselves. When others are deprived or destroyed they are rendered incapable of serving the destroyer and thereby making him/her to live a lower kind of life. The big problem with Nigeria is that everybody wants to dictate the tune and nobody wants to dance to the tunes. Henry Kissinger supports this view, he avers that "what's causing so much disharmony among nations is the fact that some want to beat the big drum, few are willing to face the music, and none will play second fiddle". They forget that a good leader is one who is a good follower. A good leader is more of a servant than the ruled. A good leader should sometimes also drop the drum and dance to the music played by the others.

4. Criticize constructively instead of destructively. As is happening in Nigeria, one individual, group or party is always at the others throat just to totally render the other useless and not to correct and encourage the person to do better. One party will be looking for loopholes in the other not to correct and guide but to destroy and render it incapable of performing even the things it used to do well. Until we learn to correct in love and to criticize with empathy, there will continue to be chaos in the country.

Pitch the future against the past: He who falls and wakes up is not a failure but he who falls and remains on the ground is the real failure. Nigeria has always bemoaned the past. They are ever ready to lay the blame of their deplorable state to their past experiences in the hands of the colonizers and the western intruders. The question I have always asked is, is 54 years not enough to right whatever wrongs that was done against the country? Will we moan our past forever? When are we going to right the wrongs. It is time we begin to apply what Jonathan Chimakonam calls 'interrogatory theory' (2014, 1-26). We should begin to interrogate our institutions, social structures, and even our belief-systems, to find out why there are not competing favorably with that of the other part of the world and how they could be made to become better. We need to know why our educational system is nose-diving instead of improving; why our power supply in spite of the monies pumped in there have failed to improve; why our roads are fast becoming mini-lakes and death traps; why our religious houses are churning out moral dwarfs and not moral giants as it should be and why our agricultural sector which use to be the pride of the nation has dwindled and by that, turning the nation into a great dependant on other nations for food. When answers to these interrogations are gotten, then our problems will be half solved. For when a problem is well identified, the right diagnosis could be administered. 


\section{CONCLUSION}

Nigerian leaders could rightly be said to be the main culprit for the dilapidating state of the country, the followers however cannot totally escape some of the blame. To build a sustainable future all hands must be on deck. Everyone must interrogate his/herself to find out the extent to which his actions or inactions contribute to the plight of Nigeria. When this honest assessment is carried out, Nigeria will be at the verge of turning around for good. Our goals will only be actualized when all make a conscientious effort to change from their past ways, to ways that will yield good fruits for the nation as a whole.

Democracy does not function well when the people that drive it are not towing the right path. It is therefore, not democracy that has failed in Nigeria, but Nigerians have failed to drive democracy well. We therefore, advocate for a conscientious effort to enthrone and consolidate the gains of democracy by all stakeholders.

\section{REFERENCES}

Akpan, C. O., \& Bassey, S. A. (2020). A critique of the social constructionist and relativistic cultural conception of child abuse. International Journal of Humanities and Innovation (IJHI), 3(1), 11-16.

Alumuna, S., Ofoegbu, R. C., \& Edet, A. S. (2017). Militancy and Kidnapping in the Niger Delta Region of Nigeria; A Recap. Elixir Social Studies, 112, 49425-49434.

Anweting, K. I., \& Ogar, O. A. (2018). Political Violence in Nigeria and Its Implication for National Development. GNOSI: An Interdisciplinary Journal of Human Theory and Praxis, 1(1), 84-92.

Asouzu, I. (2007). Ibuanyidanda; New Complementary Ontology beyond World-Immanetism, Ethnocentric Reduction and Impositions. Zweigniederlassung Zurich; Litverlag GmBh \& Co. KG Wien.

Asouzu, I. (2007). Ibuaru; The Heavy Burden of Philosophy beyond African Philosophy. Zweigniederlassung Zurich; Litverlag GmBh \& Co. KG Wien.

Bisong, P., Joseph E. and Inameti U. (2014) . "Law and Morality as Complementary Tools in the service of Nigeria". Journal of Law. Vol. 11 no 1.

Chimakonam, J. (2014). "Interrogatory Theory: Pattern of Social Deconstruction, Reconstruction and the Conversational Order in African Philosophy". Filosofica Theoretica. 3(1), 1-25.

Duke, E. O., \& Okafor, J. O. (2020). Poverty Alleviation Policies of Selected Churches in Anambra State, Nigeria. GNOSI: An Interdisciplinary Journal of Human Theory and Praxis, 3(1), 40-52.

Duke, E. O., \& Osim, S. (2020). From festival to social communion: a Nigerian experience. Przestrzeń Społeczna, 19(1), 53-70.

Duke, E. O., \& Osim, S. E. The culture of slavery in traditional context and globalised society. Przestrzeń Społeczna, 19(2).

EDET, A. (2017). Crime Control And Policing The Nation States; The Nigerian Police In Focus. International Journal of Social Sciences and Humanities Reviews, 7(2), 97-102.

Edet, A. (2017). Security Agents In Nigeria Sea Ports: A Focus On Port Harcourt Sea Port. Global Journal of Applied, Management And Social Sciences, 13. 
Egbeji, P. O. (2019). Leadership Dynamics and Peace Development in Nigeria. GNOSI: An Interdisciplinary Journal of Human Theory and Praxis, 2(2), 13-21.

Hobbes, Thomas (1951). Leviathan. London.

Ijiomah, Chris (2014). Harmonious Monism: A Philosophical Logic of Explanation for Ontological Issues in Supernaturalism in African Thought. Calabar: Jochrisan Publishers.

Irek, N. E. (2016). Music as a Tool for Communicating Good Governance in Nigeria: A Periscopic Survey of Selected Nigerian Musicians. West African Association for Commonwealth Literature and Languages Studies Journal, 4(1).

Irek, N. E. (2018). Prophetic Reflection on Good Governance in Nigeria: Discourse on Chinua Achebe's The Trouble with Nigeria Chinua Achebe and the Convolution of Immortality.

Mesiti, P. (1997). Attitudes and Altitudes. Winsconsin: Baulkham Hills.

Ndoma-Egba, V. (n.d). 15 Years of sustain7ed democracy: gains, challenges an $7 d$ prospects. Retrieved from http://www.radionigerialagos.com/index.php/news/144-15-years-ofsustained-democracy-gains-challenges-and-prospects on 10th September, 2015

Ogar, J. N., Idagu, U. A., \& Asira, A. E. (2016). The Limits Of Aj Ayer's Verification Principle As The Method In Modern Science. European Journal of Research and Reflection in Arts and Humanities Vol, 4(1).

Ogunbumi, K. (2015). 15 Years of Sustained Democracy: Gains, Challenges and Prospects". Retrieved on August 7, 2016 from www.radionigerialagos.com/index.php/news/144 - 15 - year - of - sustained - democracy - gains - challenges- and - prospects".

Ozumba, G. (2010). Philosophy and Method of Integrative Humanism. Calabar: Jochrisan Publishers.

ThankGod, S. (2018). Wike: An Agent Of National Cohesion”. Retrieved on August 7, 2016 from www. thetidenewsonline.com/2018/10/01/wike-an-agent-of-national-cohesion/".

Udoh, E. W. (2017). A Comparative Examination of Issues of Religion and Culture In Africa.

Udoh, E. W. (2017). A Comparative Examination of Issues of Religion and Culture In Africa.

Udoudom, M. D., Idagu, U. A., \& Nwoye, L. (2018). Kantian and Utilitarian Ethics on Capital Punishment. Journal of Sustainable Society, 7(1), 5-11.

Ushie, A. I. (2018). The Hermeneutic Narrative of Political Corruption: In and Beyond the Known. International Journal Of Integrative Humanism Vol. 10 No. 2, 39.

Yta, E. (2020). Objectification of women in carnival Calabar: an emerging paradigm. International Journal of Humanities and Innovation (IJHI), 3(2), 79-86. 
42 Pinisi Discretion Review

Volume 4, Issue 1, September, 2020 Page. 33- 42 